Article

\title{
Deterioration of Wood Plastics Composites by the White-Rot Fungus Pycnoporus sanguineus
}

\author{
Ivana Cesarino ${ }^{1, *(\mathbb{D})}$, Otávio Augusto Titton Dias ${ }^{2}{ }^{\mathbb{D}}$, Djanira Rodrigues Negrão ${ }^{1}$, \\ Ligia Linardi Niero Rocha ${ }^{1}$ and Alcides Lopes Leão ${ }^{1, * \mathbb{D}}$ \\ 1 School of Agriculture, São Paulo State University (UNESP), 3780, University Avenue, Botucatu, \\ São Paulo 18610-034, Brazil; djanegrao@hotmail.com (D.R.N.); ligialinardi@yahoo.com.br (L.L.N.R.) \\ 2 Faculty of Forestry, University of Toronto, 33 Willcocks Street, Toronto, ON M5S 3B3, Canada; \\ otavio.dias@mail.utoronto.ca \\ * Correspondence: ivana.cesarino@unesp.br (I.C.); alcides.leao@unesp.br (A.L.L.); Tel.: +55-143-8807-404 (I.C.)
}

Received: 31 January 2019; Accepted: 28 February 2019; Published: 6 March 2019

\begin{abstract}
Wood plastic composites (WPC) are characterized by the mixing of wood fibers with plastics, allowing the production of new products whose characteristics are in several aspects superior to those of the original products and represent an expanding class of durable and low-cost materials in which their uses can reduce the environmental footprint and the dependence on petroleum products. Nevertheless, WPC has some setbacks, including biodegradation, which shortens its life span. In this study, the wood composite was exposed to the white-rot fungus Pycnoporus sanguineus in order to evaluate its resistance to biodegradation. The WPC was prepared with a 1:1 ratio of Eucalyptus spp. bark as reinforcement agent and polypropylene as matrix. Mechanical and rheological properties and mass loss were evaluated from 15 to 120 days of fungus exposure. After 15 days, a mass loss was detected, which transmitted a negligible effect on the impact resistance of the composite. For the 120-day fungus-exposed composite, the fungus produced a biofilm under the WPC that create a special environment for lignocellulosic consuming led to deterioration of the mechanical properties and minor changes on the thermal-chemical stability of the WPC. Finally, the study gave a great indication of the susceptibility of a Eucalyptus-based composite to biodegradation.
\end{abstract}

Keywords: biodegradation; wood-plastic composite; lignocellulolytic fungus; biobased composites; Eucalyptus bark

\section{Introduction}

An increase in environmental concerns has promoted the use of natural composites with the aim of replacing materials commonly made from fossils [1,2]. Composites have been used to replace many products made exclusively with petroleum derivatives, which represents a new approach in material development [3,4]. The possibility of using recycled materials to make composites is very attractive, especially with the large amount of wood fiber and plastic waste generated daily around the world [5].

Wood-plastic composites (WPCs) are made with plant fibers (lignocellulosics) and preferably thermoplastics (matrix) as the main constituents, and, to a lesser extent, additives. The use of cellulose fibers in the composites results in more easily colonized surfaces, which are attributed to water uptake by the cellulose fibers. Woody residues are used as the co-product, such as sawdust or planer shavings, which reduces the problem of a large amount of accumulated residue [6]. Since wood-plastic composites (WPC) are most used for exterior applications, durability and weathering is an important issue. Therefore, damages caused by fungi and bacteria are factors that should be analyzed and if necessary be improved, since WPC are susceptible to biodegradation, although these materials have limited water absorption because of the wood fiber encapsulation in polymer matrix [7]. Although 
in the past WPC was considered to be durable against biodegradation, because of the wood fiber encapsulation in the thermoplastic matrix, this fact, later Morris and Cooper (1998) showed that brown and white rot fungus as well as blue stain fungus were growing on WPC boardwalk in Florida [8,9].

Several types of agricultural residues may be used as the raw material for WPCs beyond wastes from wood processing mills. Different plant-derived fibers, including sisal, coir, jute, banana, bamboo, rice straw, cereal straw, corn stalks, rice husks, and sugarcane bagasse, have been shown to be good replacement materials $[10,11]$.

WPC production requires a polymer that exhibits a melting point below $200{ }^{\circ} \mathrm{C}$, since that the natural fibers are degraded at high temperatures [12-14]. Thermoplastic resins can be reused after melting by heating, while still maintaining their optical and mechanical properties [15]. Polypropylene is a flexible and opaque crystalline thermoplastic. It has been largely used due to its mechanical performance, thermal-chemical stability, low density, and high molding characteristics $[15,16]$.

WPCs are made with a percentage of renewable resources that varies according to their purpose. The ratio of natural polymers to be incorporated into a WPC can show desirable properties even over $50 \%$ [17]. Various segments, such as building and construction, automotive components, industrial and consumer goods, furniture and several use WPCs, can compete with materials made with petroleum-based materials $[18,19]$. WPCs possess a number of advantages, including their improvement of mechanical performance regarding conventional plastics, which reduces the environmental impact. Other advantages include their low cost and density per unit volume, non-toxicity, low power consumption to produce, and acceptable specific strength [20,21]. However, compared to petroleum-based composites, WPCs lack the variability of mechanical properties as a result of the weak chemical interaction between the wood-polymer interfaces [22]. Another point that must be considered is the chemical instability of wood fibers at high temperatures and the high water absorption that may cause poor adhesion between the fiber and matrix [11,23].

Durability of the WPC is inseparable from the question of degradability. Durability determines the usefulness of composite materials in a particular environment. The degree of degradation can be evaluated by several ways, including estimating the change of color and appearance of the composites, weight losses, and loss of mechanical properties [7,24].

Water presence in the material is a vital factor for fungal degradation. WPC materials have restricted water and moisture absorption due to fiber encapsulation in the matrix [7]. WPCs can suffer degradation caused by photodegradation through ultraviolet light and heating by sunlight [25]. Regarding biotic factors, only a few species of fungi and bacteria can cause damage to WPCs, especially when abiotic factors are the primary cause of deterioration [26]. However, there is a large difference in abilities between species and even between microorganisms. This biodiversity is the result of different enzymatic systems associated with the biogeographical origin and food source, which strongly influence their ability to consume lignocellulosic materials [27]. Therefore, is essential to analyze the environment where the material will be applied, as well as the conditions under which it will be exposed, respecting the limits of its use $[9,28,29]$.

Among the basidiomycetes, the genus Pycnoporus has been investigated due to its high ability to biodegrade and/or fragment composites, natural polymers, such as lignin, water pollutants and other recalcitrant compounds [30-32]. The aim of this work is to determine the contribution of a basidiomycete fungus to potential losses in the hardness, impact strength (toughness) and weight loss of a WPC, giving an indication of the susceptibility of a Eucalyptus-based composite to biodegradation. Pycnoporus sanguineus is a white-rot fungus commonly found in native and planted forests in Brazil. It has been studied due to its capacity to biodegrade Eucalyptus wood [33]. 


\section{Materials and Methods}

\subsection{Wood-Plastic Composite Preparation}

Polypropylene H-107 (density of $0.905 \mathrm{~g} \cdot \mathrm{cm}^{-3}$ ) was supplied by Braskem, São Paulo, Brazil. The compatibilizer used was Bondyram 100, Polyram Plastic Industries with a melting point of $150-170{ }^{\circ} \mathrm{C}$, which is a maleic anhydride grafted polypropylene (MAPP) recommended as an effective compatibilizer for fiber-reinforced polypropylene composites. Maleic anhydride is the most common coupling agent used in natural fiber-PP biocomposites. This process results in the formation of covalent bonds across fiber-matrix interface. The main difference of maleic anhydride with other coupling agents is that it is mostly used to modify PP instead of natural fibers. Studies indicate an improvement in wood fiber-PP matrix bonding in the presence of compatibilizers or coupling agents such as MAPP [24].

Eucalyptus bark was milled in a Wiley-type mill to a particle size of 18 mesh and blended with polypropylene (PP) at a ratio of 1:1, 2\% MAPP. Composites were prepared in a twin-screw extruder, L:D 36 (Coperion model ZSK-25, Stuttgart, Germany). In order to prevent PP degradation and provide the fusion between fiber and polymer, the processing conditions in the extruder were $180 \mathrm{rpm}$ and the temperature profile of $190,190,180$, and $180^{\circ} \mathrm{C}$ at the four heating zones and $160{ }^{\circ} \mathrm{C}$ at the dye. After that, the material was chopped into granules (SAGEC brand, model GS mill 70). The next step was to inject the composite granules into an injection-molding machine (Sandretto Model 65/247) for sampling preparation for mechanical tests. Both fibers and granules were previously dried at $105^{\circ} \mathrm{C}$ for the production of the composites. The parallel screws are modular, along the barrel length with screw shaft sections that can be changed depending on the objectives (conveying, dispersive mixing, distributive mixing, etc.). The design used is showed in Figure 1. The feeding process was the one in which both components are introduced at the same time to avoid overheating.

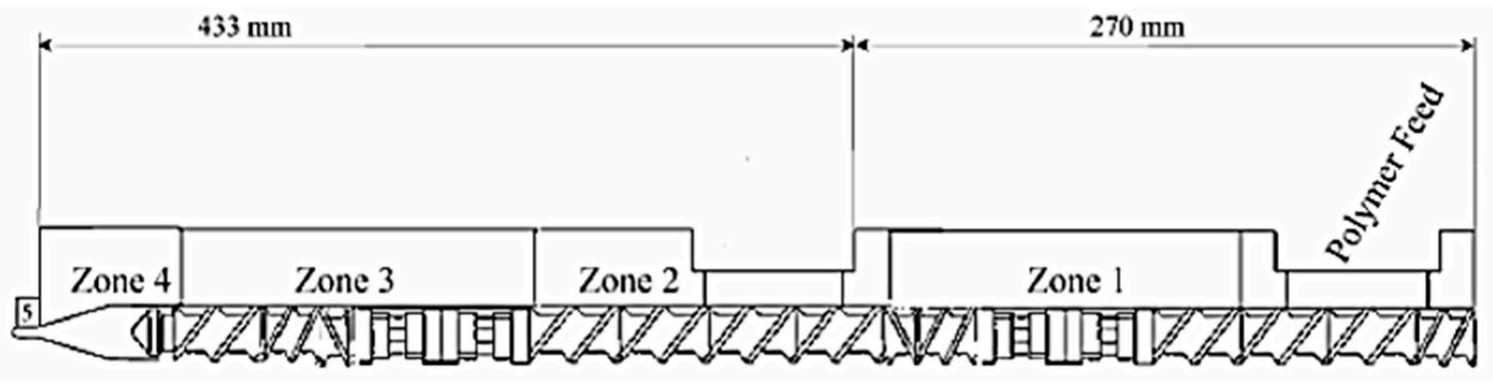

Figure 1. Screw configuration used in the experiment.

\subsection{Fungus Cultivation}

Pycnoporus sanguineus was macroscopically identified at the Botanic Institute of Sao Paulo by Dr. Adriana Melo Gugliota and also by sequencing the internal transcribed spacer (ITS 1 and ITS 4) region of the ribosomal DNA. The species was deposited in the Culture Collection of Algae, Cyanobacteria and Fungi of Botanic Institute (CCIBt), Sao Paulo-SP, Brazil, with number CCIBt 3817.

Two steps of fungi grown were used. First, the fungus was grown on potato dextrose agar (PDA) prepared on Petri dishes $\left(5\right.$ day $/ 28^{\circ} \mathrm{C}$ ). The second step was to prepare a eucalyptus-based substrate (ES-substrate) made with Eucalyptus spp. sawdust, wheat, corn bran and calcium carbonate (41:1:1:1, $\mathrm{w} / \mathrm{w}$, respectively) at $60 \%$ humidity. The blend was sterilized by autoclaving for $4 \mathrm{~h}$ [34]. After cooling, $150 \mathrm{~g}$ of the ES-substrate was placed in glass Petri dishes $(140 \times 20 \mathrm{~mm})$, followed by autoclaving at $121^{\circ} \mathrm{C}$ for $15 \mathrm{~min}$. One PDA disk $(\phi 0.9 \mathrm{~cm})$ was placed in the center of the ES-substrate. For complete mycelial colonization, the plates were incubated for a week at $28^{\circ} \mathrm{C}$. 


\subsection{Composite Preparation for Biodegradation Assay}

The sterilization method for the WPC was as follows. The samples were previously cleaned with $70 \%$ ethanol and oven dried at $60{ }^{\circ} \mathrm{C}$ for $12 \mathrm{~h}$. For minimizing microbial contamination, the WPC samples were exposed each side under ultraviolet light for $5 \mathrm{~min}$. Under aseptic conditions, five WPCs were placed under the fungus-colonized ES-substrate and incubated at $30{ }^{\circ} \mathrm{C}$ at $60 \%$ humidity, mimetizing the local environment, for 120 days.

The experimental design was completely randomized with six periods of evaluation $(15,30,45$, 60, 90, and 120 days), with ten replicates. Melt flow, impact strength and hardness composed the rheological, physical and mechanical assays, and thermogravimetric analysis (TGA) and infrared spectroscopy (FTIR) composed the chemical analysis. Scanning electronic microscopy (SEM) observations were carried out at 60 and 120 assay periods and weight losses were evaluated for the overall period.

\subsection{Melt Flow Index Test}

This test was performed according to the standard ASTM D1238 [35] using a plastometer (JJH). The melt flow index was measured at a temperature of $230{ }^{\circ} \mathrm{C}$, a weight of $2.16 \mathrm{~kg}$ and a cut time of $10 \mathrm{~s}$.

\subsection{Mechanical Testing}

\subsubsection{Impact Test}

The measurements were performed using an Izod-type notched sample (Izod Impact Tester, Tinius Olsen) according to the standard ASTM D256 [36] at an impact speed of $4 \mathrm{~m} \cdot \mathrm{s}^{-1}$.

\subsubsection{Hardness Test}

The relative hardness of the composites was conducted according to ASTM D2240 [37] using a Zwick analogy hardness tester. The indenter was pressed over the sample for $10 \mathrm{~s}$ at five random points.

\subsection{Weight Loss}

The weight loss, because of the degradation, does not always reflect the actual damage that has occurred in the wood. In case of the WPC, the situation is different. For the WPC, in opposite of solid wood, the natural fibers are encapsulated and most protected by the plastics matrix, therefore its mechanical performance is less sensitive of fungal degradation compared to weight loss. Nevertheless, the absorption of moisture and afterward drying leads to wood particle debonding from the matrix and consequently causes more significant mechanical changes. Therefore, the main indicator of fungal degradation should be weight loss [7]. The fungal mycelium that recovered WPC samples was removed with tap water, oven dried for $12 \mathrm{~h}$ and weighed. Weight losses were calculated based on an average of 10 samples (two Petri dishes) considering the initial (before inoculation) and final weight (after fungus exposure), as a percentage, based on the standard ASTM D2017 [38].

\subsection{Model Fitting}

To perform the increase in melt flow $\left(\mathrm{g} \cdot 10^{-1} \mathrm{~min}\right)$ in time $(\mathrm{d})$, a nonlinear regression monomolecular growth model was fitted with melt flow $=\alpha\left(1-e^{-\beta \text { time }}\right)+u_{i}$. In this model, $\alpha$ is the asymptote parameter $\left(\mathrm{g} \cdot 10^{-1} \mathrm{~min}\right), \beta$ is the parameter related to the velocity of growth, $u$ is the normal random error with zero mean and constant variance, and the indexes $i$ and $j$ are, respectively, related to the observations and replications. The coefficient of determination obtained $\left(R_{c}^{2}\right)$ is defined as the square of the correlation coefficient between the observed and fitted values by the model [39]. 
With regard to the impact strength $(\mathrm{J} / \mathrm{m})$ and hardness (shore-D) analysis, a generalized linear model was performed, with a Gamma distribution error and log link function [40,41]. The goodness of the fit of the models was measured by an analysis of deviance [40].

Aiming to evaluate the curves of weight losses (\%) versus time (d) and treatments, a generalized linear model was performed with a Gamma distribution error and log link function [40,41]. The goodness of fit of the models was measured by analysis of deviance [40].

\subsection{Scanning Electron Microscopy}

The samples were sputter coated with a thin layer of gold to avoid an electrostatic charge during examination. The surface morphology of the composites was examined by SEM using a Quanta 200 (FEI Company, Hillsboro, OR, USA).

\subsection{Fourier Transform Infrared Analysis}

FTIR analysis was carried out using a Bruker spectrophotometer (Vertex 70, Bruker Optics, Ettlingen, Germany) equipped with a diamond crystal, with the interface between the samples and Infrared energy. Samples were analyzed between 3997 and $400 \mathrm{~cm}^{-1}$ in attenuated total reflectance mode with a resolution of $4 \mathrm{~cm}^{-1}$.

\subsection{Thermogravimetric Analysis}

The influence of the decayed wood on the thermal properties of the WPCs was determined by TGA using simultaneous thermal analysis, STA 409 NETZSCH (Selb, Germany). The samples of control and degraded WPCs were heated from $30{ }^{\circ} \mathrm{C}$ up to $700{ }^{\circ} \mathrm{C}$ at a heating rate of $20^{\circ} \mathrm{C} \cdot \mathrm{min}^{-1}$ under an atmosphere of synthetic air at a flow rate of $10 \mathrm{~mL} \cdot \mathrm{min}^{-1}$. Approximately $10 \mathrm{mg}$ of materials was used for each TGA.

\section{Results and Discussion}

The biodegradation capacity of Pycnoporus sanguineus has been studied on various highly permanent lignocellulosic substrates, such as Eucalyptus spp. wood and stumps [42,43] and phenolic compounds, like phenols and bisphenols [44]. However, there are several species of fungi or strains (same species but collected from different geographic areas) that can potentially be applied to biodeterioration and biodegradation assays. In this context, the white-rot fungus $P$. sanguineus was used as a decaying agent of the WPC made with polypropylene and Eucalyptus spp. fiber in order to evaluate the susceptibility of the composite to fungal exposure.

\subsection{Melt Flow Index}

The viscosity decreases according to the exposure time of the composite to P. sanguineus (Figure 2). A positive effect of biological treatment with time was observed $(p<0.0005) . R^{2}$ calculates the expected melt and the observed melt. When the melt reaches $13.6 \mathrm{~g} \cdot 10^{-1} \mathrm{~min}$, the curve tends to stabilize, which means that independent of time, the index will be the same.

The melt flow index analysis showed that the biological attack caused changes in the rheological characteristics of the WPC. This parameter is an important property related to plastic recycling, molecular weight, and mechanical strength [45]. Some abiotic factors can accelerate fungal biodegradation, as observed by Butnaru et al. [46] who exposed $\gamma$-irradiated composite to the fungus Bjerkandera adusta. A longer fungi action diminishes the molecular weight, thus decreasing the complex viscosity. The formation of small chains of propylene can occur, causing damage to various mechanical properties [47]. 

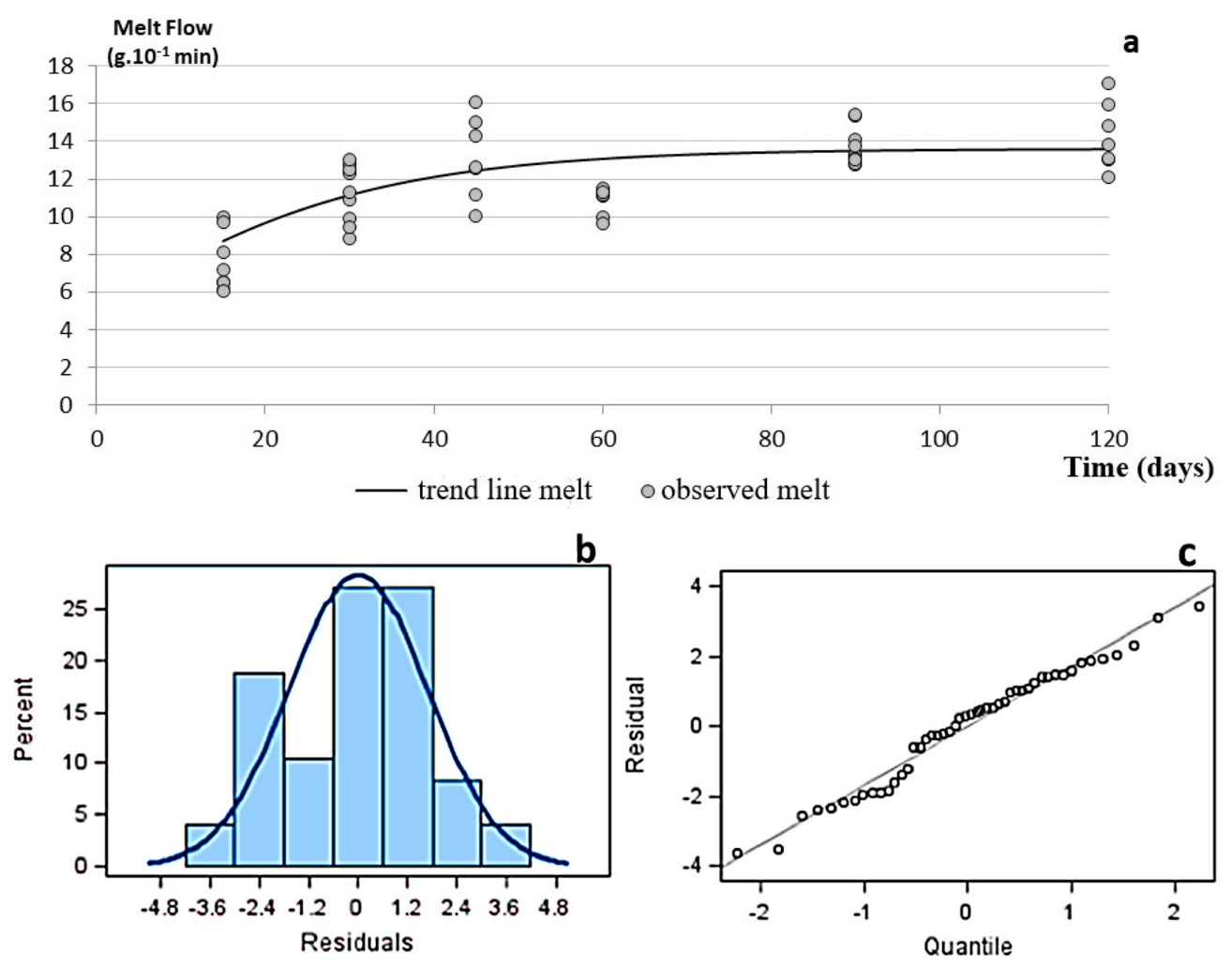

Figure 2. Nonlinear monomolecular growth fitted model for P. sanguineous melt flow $\left(\mathrm{g} \cdot 10^{-1} \mathrm{~min}\right)$ in time (d) (a) meltflow $=13.60\left(1-e^{-0.054 \text { Time }}\right) ; R_{c}^{2}=62.80 \%$. The coefficient of determination $\left(R_{c}^{2}\right)$ is defined as the square of the correlation coefficient between observed and fitted values by the model [38]. The residual analysis and quantile are in $(\mathbf{b}, \mathbf{c})$, respectively, with the test of normality by Kolmogorov-Smirnov ( $p>0.15)$.

\subsection{Impact Strength}

The impact strength of the biodegraded and non-biodegraded samples did not show a statistical difference at $5 \%$ probability $(p=0.1647)$. However, under the impact parameter for the biological treatment, an effect with time occurred (Figure 3) and an exponential regression equation could be adjusted: impact $=e^{1.8992-0.0038 t i m e}$, with $p<0.0001$ for the estimation of parameters.

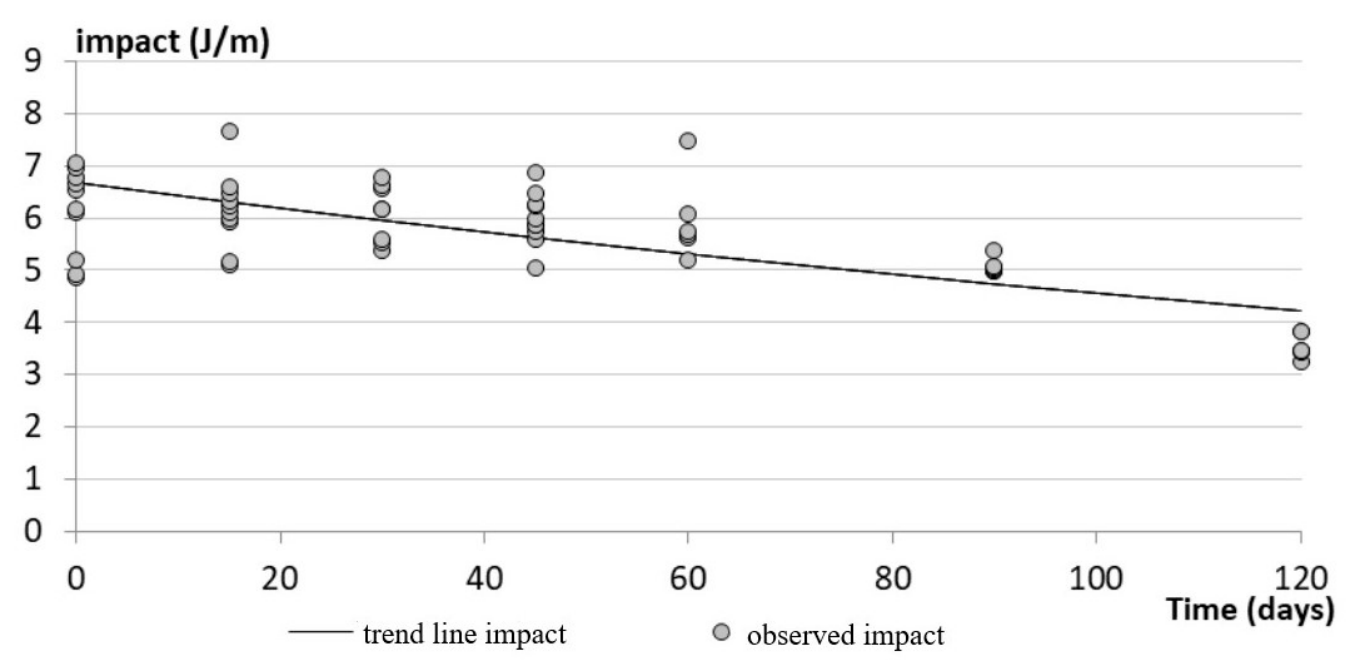

Figure 3. Nonlinear exponential model of impact $(\mathrm{J} / \mathrm{m})$ as a function of time (d) for P. sanguineous treatment: impact $=e^{1.8992-0.0038 t i m e}$, with the parameters of the model significant $(p<0.0001)$. 
The impact response of the natural fiber composite is highly influenced by the interfacial bond strength. Minor changes in the interface between the fiber and polymer matrix in the composite can be reflected in substantial changes in the energy dissipated during the impact test [48]. The exposure time of the WPC to the fungus is very important to allow changes in the structure of the lignocellulosic material, thereby increasing accessibility to the enzymes capable to biodegrade wood components [49].

\subsection{Hardness}

For the hardness values (shore-D), a statistical effect was observed at $5 \%$ probability $(p<0.0005)$, with a control media (epm) of $73.45(0.3542)$ and P. sanguineus $71.40(0.2062)$. The hardness decreases significantly with biological exposure (Figure 4 ).

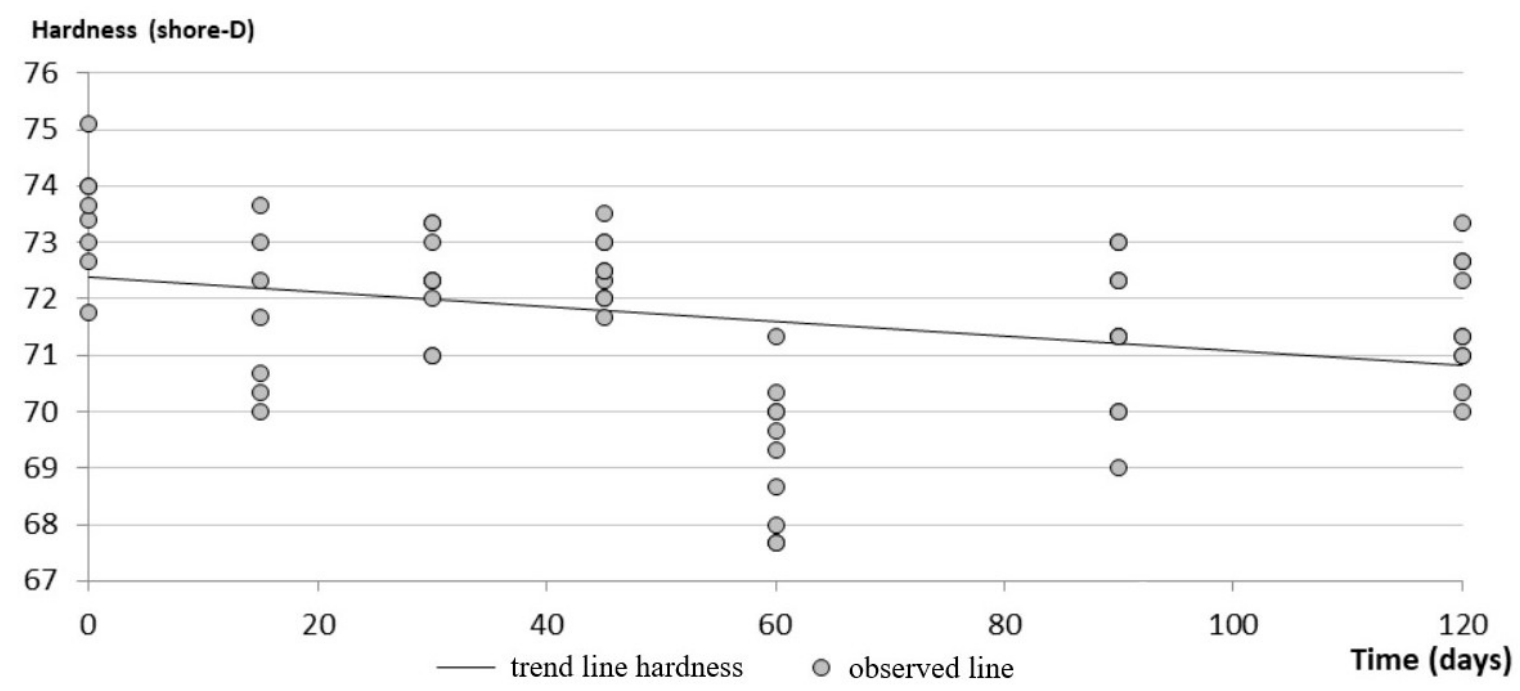

Figure 4. Nonlinear exponential model of hardness (shore-D) as a function of time (d) for P. sanguineous treatment: hardness $=e^{4.2820-0.0002 t i m e}$, with the parameters of the model significant $(p<0.0001)$.

Kord [50] observed that the hardness of WPCs increased with addition of wood flour. This phenomenon is probably due to the weakening of interfacial bonds between the PP and the natural fiber. The hardness of the composites determines the risk and perforation capacities of the materials. Therefore, natural fiber contributes to the resistance of friction and wears [51,52].

According to Hosseinihashemi et al. [53], the hardness of composites with natural fiber and PP decreased $15 \%$ after 12 weeks of fungal exposure, but remained constant for four weeks. According to the authors, there was no significant difference between treatments with brown- and white-rot fungi.

\subsection{Weight Losses}

Weight loss is the main indicator of fungal degradation for WPC materials. Weight losses with time and between treatments had no statistical significance at $5 \%$ probability. For the biodegraded samples and control, the weight losses were $0.497 \%$ and $-0.028 \%$ (standard errors of 0.404 and 0.320 ), respectively.

Although the biodegradability of PP can be improved by adding at least $5 \%$ of wood sawdust to the composite [54], very low weight losses were observed in this study compared to those described in the literature [55]. Therefore, clear evidence of fungal attack on composites is dependent on the wood content, as well weight losses being governed by the fungal species [56]. In addition, weathering treatment improves fungal attack [57].

Weight losses tend to be lower for WPCs containing PP due to the hydrophobic nature of the plastic matrix [55], the high molecular weight and some types of functional groups [58]. Conversely, materials with the presence of functional groups, like $\mathrm{C}-\mathrm{O}-\mathrm{C}$ and $\mathrm{C}=\mathrm{O}$, favor the biodegradation process [59]. Due to the importance of the wood in the performance of WPCs, even small mass losses 
can negatively affect the mechanical properties of the composite, especially if the fungus attack occurs at the wood and plastic interface [58].

Biological resistance is often measured by the percentage of weight loss [60]. Therefore, it is a reliable parameter for assessing the biodegradability of a WPC. Lopez et al. [61] evaluated different species of fungi through the mechanical behavior of WPCs after biological exposure. The authors found that the composites could be partially degraded by white-rot fungi, which cause mass losses above $10 \%$. Therefore, the authors indicated the use of white-rot fungi on composite biodegradation assays.

According to Zabihzadeh et al. [62], white- and brown-rot fungi caused weight losses of $~ 11 \%$ after 14 weeks, in materials made with PP, bagasse flour and graphite, added with MAPP. Similarly, Hosseinihashemi et al. [53] observed that white- and brown-rot fungi caused weight loss of $\sim 6 \%$ after 16 weeks in a composite based on sugarcane bagasse and PP. According to H'ng et al. [63], P. sanguineus caused weight loss of $\sim 3 \%$ in a composite made with wood and PP. Therefore, the fungus species used in this study has promising characteristics that can be highly improved by causing abiotic deterioration under the composite.

\subsection{Scanning Electron Microscopy}

The SEM images show the morphological changes of the surface after WPC biodegradation (Figure 5). Compared to non-biological exposed samples (Figure 5A,B), a relatively cleaner surface is observed for the 60 and 120 days fungus-exposed WPCs (Figure 5C-F). In these samples, voids on the surface can be seen, which probably helped the fungus to remove part of the non-included lignocellulosic compounds into the PP.

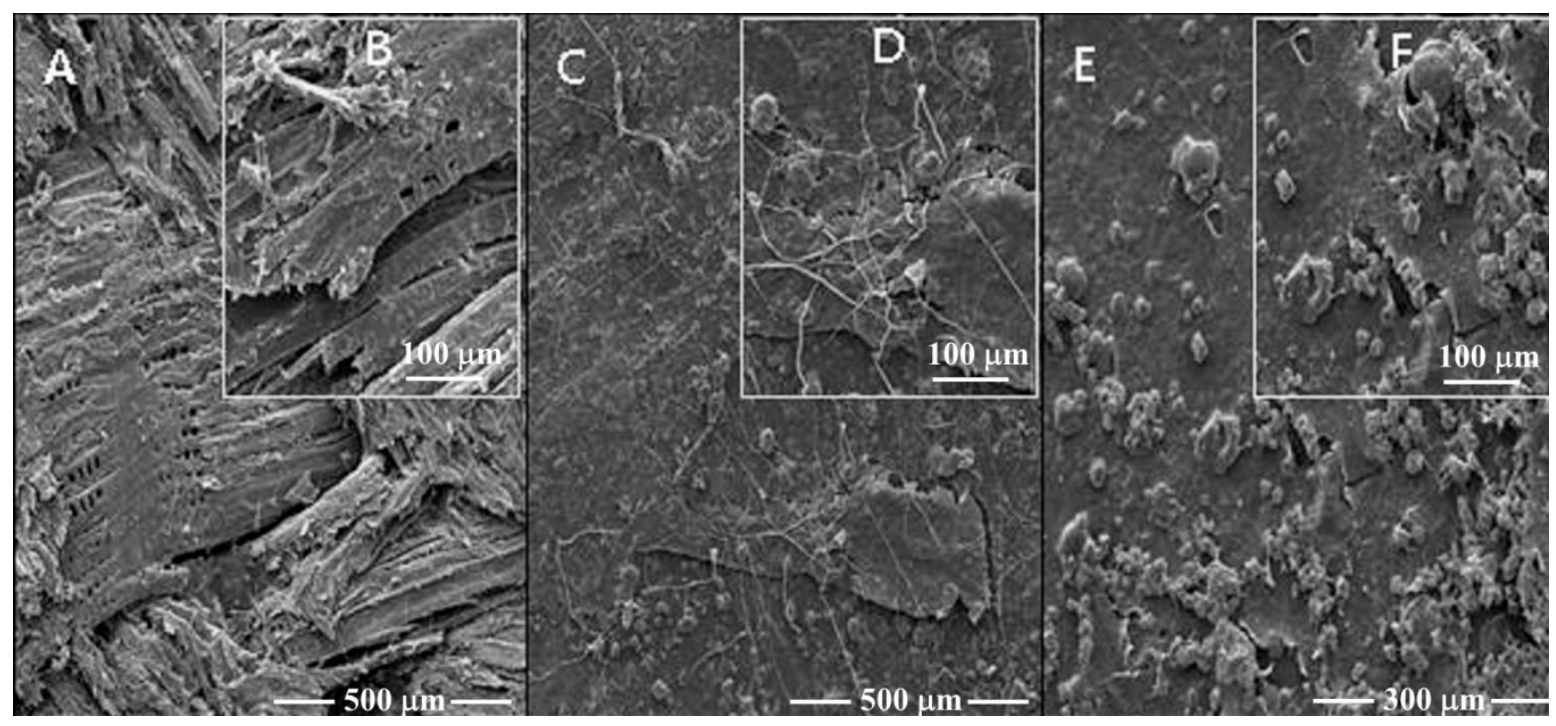

Figure 5. Micrographs of wood-plastic composites (WPCs) after non-biological treatment (A,B) and colonized by $P$. sanguineus for 60 days (C,D) and 120 days (E,F). Micrographs A, C, and E are 500× zoom, while B, D, and F are $1000 \times$ zoom.

In general, plastics are resistant to fungal attack. For wood-based composites, the main concern is that they can be susceptible to biodegradation once the fungi consume lignocellulosic components very easily [64]. In this study, WPCs were superficially colonized by P. sanguineus (Figure 5D), as can be seen by the hyphae covering the surface of the 60 days samples. The WPC weight losses were low, thus we supposed that the fungus could not easily penetrate in the material, with it only producing a biofilm, as also observed by Catto et al. [57]. This biofilm, composed of vigorous mycelia, is produced to maintain the substrate water content, which is essential to the enzymatic activity and other metabolic functions. The ratio of wood to plastic, particle size, and the presence of additives closely influence the moisture uptake [65], which is the beginning of the biodegradation process. 
In this study, we observed a slight increase in the weight of the WPCs (data not shown). Lignocellulosic fibers easily absorb moisture, which induces swelling, creating a few ruptures on the composite's surface. Biodegradation of lignin exposed part of the cellulose content, which is highly hygroscopic, thus increasing mechanical modifications into the composite caused by water absorption. The rates of decay can also fluctuate according to the method of WPC exposure to fungus, as well as the type of lignocellulosic material [64]. The water absorption ability of WPCs comes from them being used both indoors and outdoors. This means that the ratio of wood to plastic and sunlight exposition (and other abiotic factors that can initially cause damage to the WPC surface) are factors that must be considered in cases to minimize the risk of microbial attack [65].

\subsection{Fourier-Transform Infrared Analysis}

In general, the fungus did not cause serious chemical changes in the WPCs. The most modifications occurred in the 30 and $45 \mathrm{~d}$ samples. Specifically, the spectra of the $30 \mathrm{~d}$ samples showed prominent changes at $1035 \mathrm{~cm}^{-1}$, related to C-O and C-C-O stretching of lignin and carbohydrates. Only in this treatment were shoulders observed at 1595 and $1730 \mathrm{~cm}^{-1}$, which are related to the aromatic ring vibration of lignin and ketone $\mathrm{C}=\mathrm{O}$ stretching of hemicellulose, respectively (Figure 6).

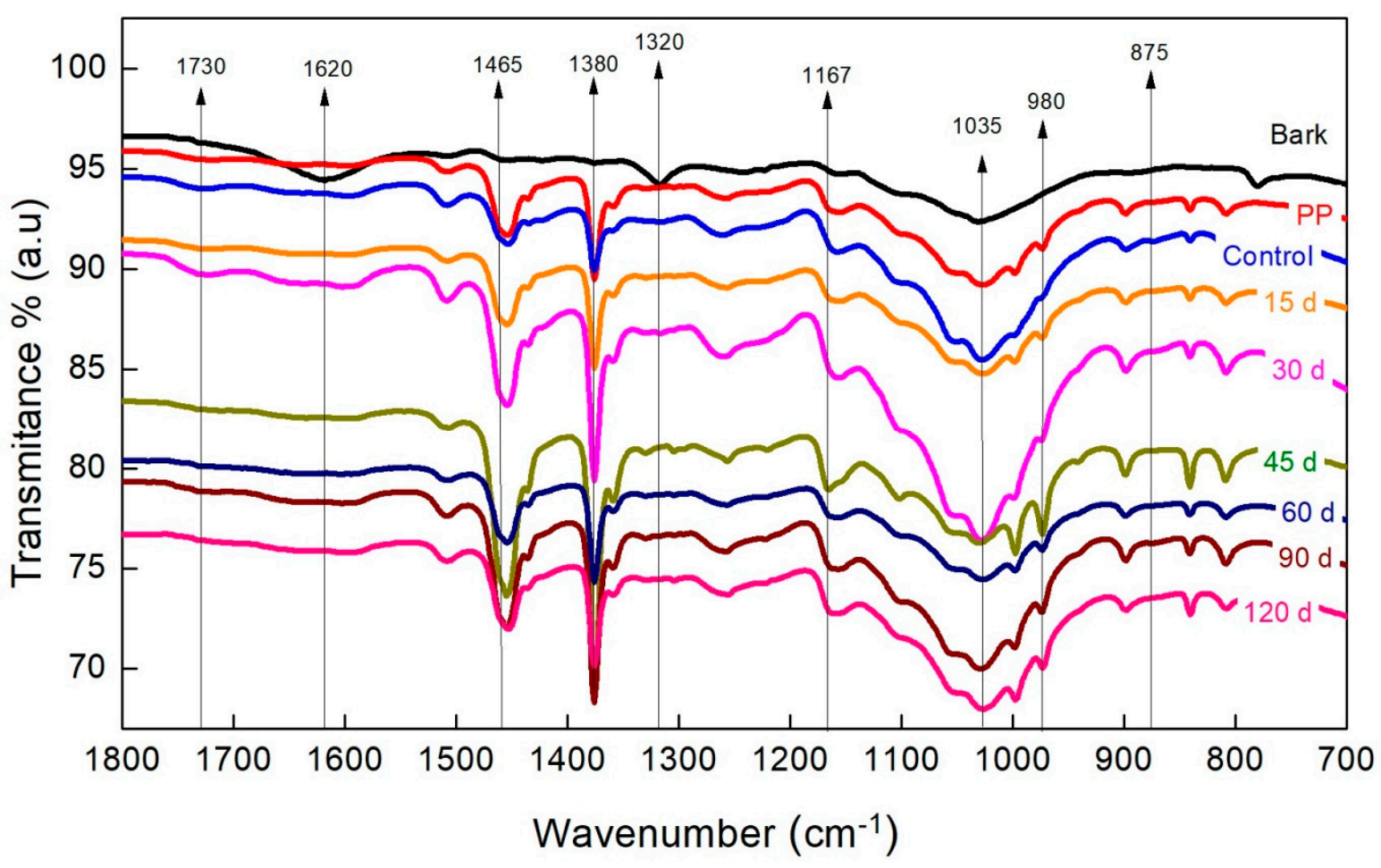

Figure 6. Fourier Transform Infrared partial spectra $\left(1800\right.$ to $\left.700 \mathrm{~cm}^{-1}\right)$ of WPC samples exposed to P. sanguineus for different periods.

The spectra from 45-day samples showed more visible peaks in the range of 842 to $1000 \mathrm{~cm}^{-1}$, which are related to the glycosidic linkage of hemicellulose and the $\mathrm{C}-\mathrm{O}$ vibration of cellulose. The peak at $1167 \mathrm{~cm}^{-1}$ is related to the C-O-C linkages of cellulose and hemicellulose and the peak at $1380 \mathrm{~cm}^{-1}$ is related to the $\mathrm{C}-\mathrm{H}$ bending of all three major components of the wood, while $1363 \mathrm{~cm}^{-1}$ is related to $\mathrm{CH}$ deformation (symmetric). The peak at $1465 \mathrm{~cm}^{-1}$ is related to $\mathrm{C}-\mathrm{H}$ deformation in lignin and carbohydrates [66-68]. Compared to the PP samples with the same treatment, modifications of the peaks at 808,842 , and $980 \mathrm{~cm}^{-1}$ are observed, which are related to C-H out-of-plane deformation [69]. These peaks are absent in the control treatment, but they reappear in the spectra of the 120 day samples. This can be related to the exposure of PP after lignocellulosic biodegradation, which again exposed these C-H deformations in the range of 975 to $998 \mathrm{~cm}^{-1}$ (Figure 7). 


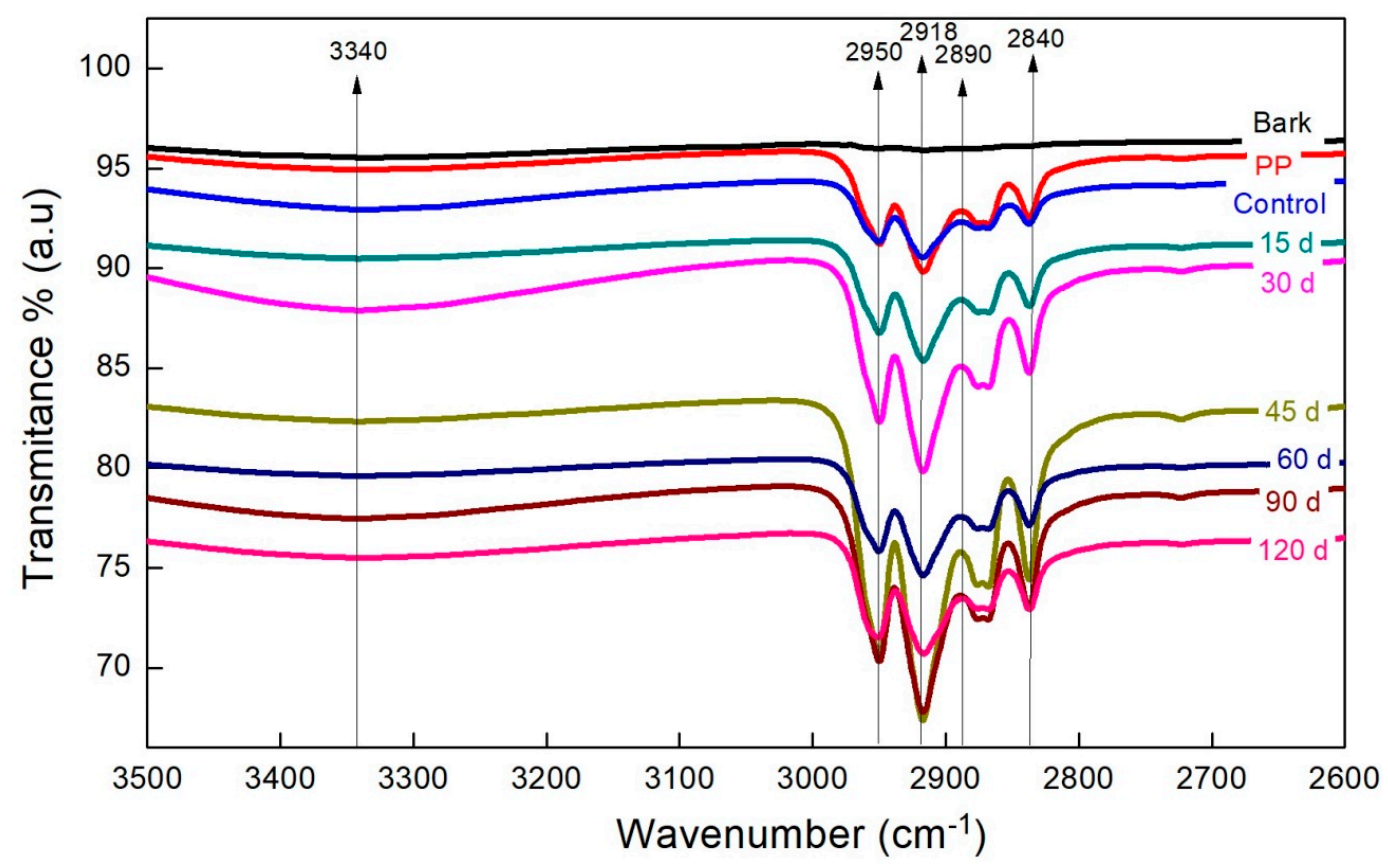

Figure 7. FTIR partial spectra (3500 to $2600 \mathrm{~cm}^{-1}$ ) spectra of WPC samples exposed to P. sanguineus for different periods.

Through the FTIR spectra, it is clear that the basidiomycete P. sanguineus was able to consume, even to a small extent, the three major components of the bark present in the WPCs after $30 \mathrm{~d}$. In this case, a long period of exposure makes a slight difference if compared with the $120 \mathrm{~d}$ samples. The ability to modify natural or petroleum-based polymers is highly dependent on the species of fungus. Basidiomycetes fungi, such as Schyzophyllum commune, Phanerochate sordida and Pycnoporus sp., selectively removed lignin, hemicellulose, and pectin of a composite made with hemp [70]. Conversely, Kartal et al. [31] did not observe biodegradation of lignin in a composite made with $70 \%$ wood. Thus, the remaining lignin can offer an antioxidant effect to the PP [46]. Crabbe et al. [71] observed the ability of four species of fungi to use polyester as a sole carbon source. They noted that Curvularia senegalensis produced extracellular polyurethane (PUase) that displayed esterase activity. PP has numerous tertiary carbons it oxides much more quickly than polyethylene [72]. In addition to microbial exposure, abiotic factors strongly contribute to WPC degradation or deterioration processes. For example, ultraviolet-B and ultraviolet-A radiation are responsible for direct photodegradation, initiating photo oxidation. The visible part of sunlight accelerates polymeric degradation by heating, as well as infrared radiation accelerating thermal oxidation. Abiotic factors can be considered as a first important step to help microbial degradation, although biodegradation depends on different factors that include polymer characteristics, the species of organism, and the nature of the pretreatment [25]. FTIR spectroscopy analyses give a semi-quantitative overview that can estimate the polymer's degradation degree of fungus-exposed WPCs [46].

\subsection{Thermogravimetric Analysis}

The TGA determined the thermal stability and degradation behavior of the WPCs, which are dependent on the change in chemical composition due to fungal biodegradation. TGA and derivative thermogravimetric (DTG) analysis exhibited the weight loss procedures (Figure 8) and its derivative (Figure 9), which provides the point at which the weight loss is most apparent. It was found that the initial weight loss $(\sim 5 \%)$ occurs at temperatures below $100{ }^{\circ} \mathrm{C}$ due to the loss of surface moisture of the lignocellulosic fiber. Above this temperature, the water absorbed mainly by hemicellulose and amorphous cellulose within the cell walls of biomass (inherent moisture) is removed [13]. On this 
basis, the fibers into the WPCs can be encapsulated by the plastic, minimizing the water absorption that favors the fungal attack.

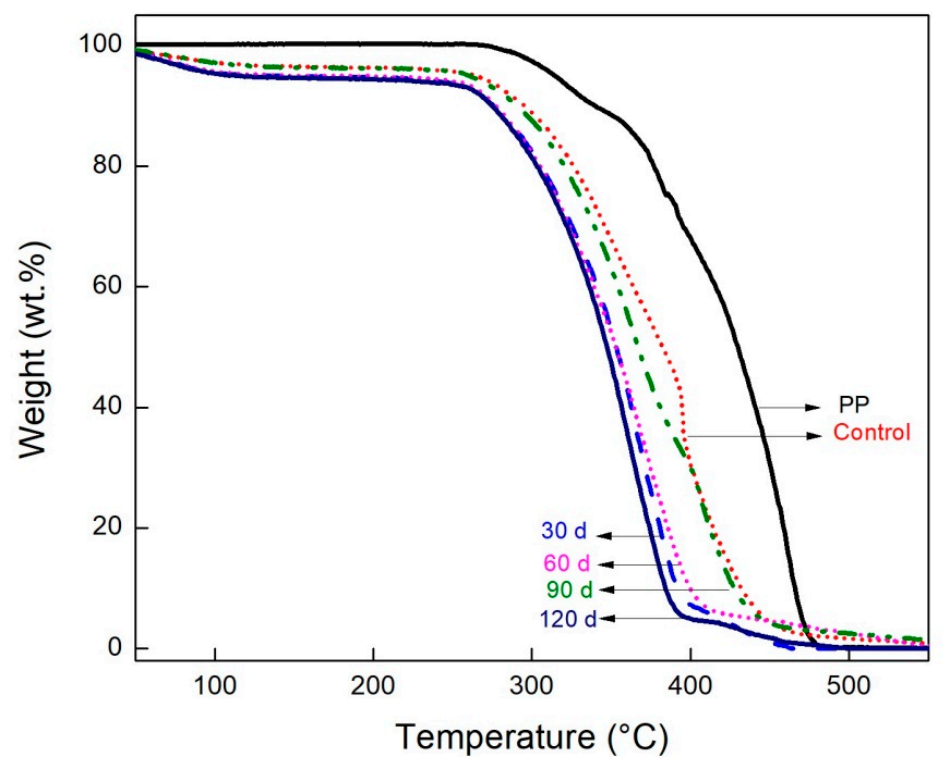

Figure 8. Thermogravimetric analysis (TGA) curves of PP, control sample (WPC non-biological treatment) and WPCs colonized by $P$. sanguineus for 30, 60, 90, and 120 days.

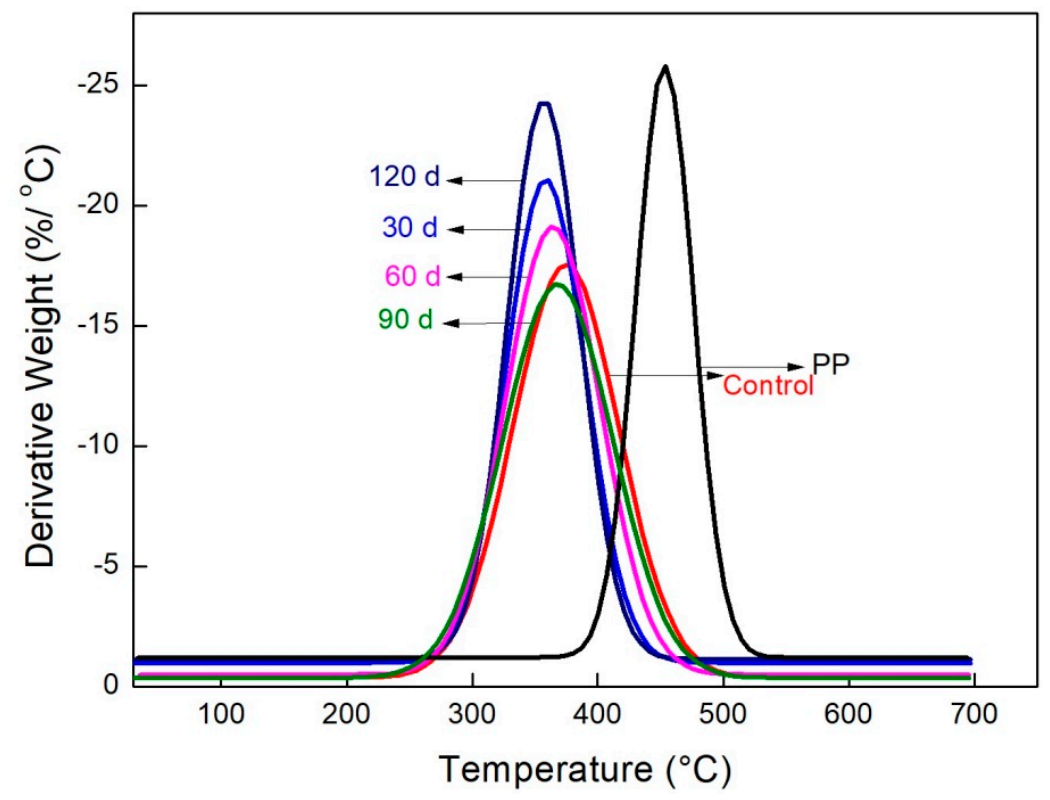

Figure 9. Derivative thermogravimetric (DTG) curves of PP, control sample (WPC non-biological treatment) and WPCs colonized by P. sanguineus for 30, 60, 90, and 120 days.

The DTG measurements of the initial decomposition temperature $\left(T_{i}\right)$ and maximum pyrolysis temperature $\left(\mathrm{T}_{\mathrm{m}}\right)$ of the WPCs and neat PP are showed in Table 1. For all WPCs, $\mathrm{T}_{\mathrm{i}}$ occurred between 230 and $250{ }^{\circ} \mathrm{C}$, which is typical of wood. The degradation of PP begins at approximately $285^{\circ} \mathrm{C}$. The $\mathrm{T}_{\mathrm{m}}$ value of the control samples was $374^{\circ} \mathrm{C}$, and for $30,60,90$, and $120 \mathrm{~d}$ fungus-exposed WPCs, the maximum temperatures were $358,364,368$, and $357^{\circ} \mathrm{C}$, respectively. 
Table 1. Degradation temperatures obtained from derivative thermogravimetric (DTG) analysis.

\begin{tabular}{ccc}
\hline Samples & $\mathbf{T}_{\mathbf{i}}\left({ }^{\circ} \mathbf{C}\right)$ & $\mathbf{T}_{\mathbf{m}}\left({ }^{\circ} \mathbf{C}\right)$ \\
\hline PP & 285 & 453 \\
Control & 233 & 374 \\
$30 \mathrm{~d}$ & 247 & 358 \\
$60 \mathrm{~d}$ & 245 & 364 \\
$90 \mathrm{~d}$ & 234 & 368 \\
$120 \mathrm{~d}$ & 250 & 357 \\
\hline
\end{tabular}

The weight loss step between 200 and $400{ }^{\circ} \mathrm{C}$ corresponds to the degradation of hemicellulose and cellulose from Eucalyptus bark [73]. In this temperature range, we can notice that the TGA curves of the fungus-exposed samples displace gradually to lower temperatures in relation to the control sample (Figure 8). These data indicate the loss of WPC stability due to the degradation of lignocellulosic biomass by $P$. sanguineus. At $\sim 280^{\circ} \mathrm{C}$, most of the hemicelluloses depolymerize by releasing acetic acid. The major decomposition peak was attributed to the cellulose decomposition due to cleavage of the glycosidic linkage between the monomer units liberating side hydroxyl groups [73-76]. It is well known that cellulose is composed of a long unbranched polymer of glucose and its semi-crystalline structure is highly ordered, which gives greater thermal stability to the molecule. Alternatively, hemicellulose is composed of several saccharides (xylose, mannose, glucose, galactose, and so on). Therefore, it presents an amorphous and branched chain structure that is easily degraded at lower temperatures [77].

Lignin is a complex structure with decomposition occurring over a wide range of temperatures from 100 to $900{ }^{\circ} \mathrm{C}$ [77]. The stage of thermal degradation between 375 and $500{ }^{\circ} \mathrm{C}$ involves, mainly, the lignin macromolecule degradation and also the highest amount of char residues, which are composed from benzene rings $[78,79]$. The presence of these aromatics rings provides thermal stability to the lignin structure [78]. In addition, in this range of temperatures, we observed a loss of thermal stability of the fungus-exposed WPCs.

The main decomposition range of lignin for Eucalyptus bark overlaps with the processing temperatures of $\mathrm{PP}$, which affects the TG parameters of the polymer. The decomposition of the major PP matrix chains occurred at $453{ }^{\circ} \mathrm{C}$ (Table 1), although it is completely decomposed at $\sim 480{ }^{\circ} \mathrm{C}$.

The thermal stability of the PP decreased with the use of wood as a reinforcement due to the formation of wood char during pyrolysis that promotes the formation of a low molecular weight product from PP, as also observed by Jakab et al. [80].

\section{Conclusions}

Wood-plastic composites (WPC) products face an important market limitation that is its biodegradation, although some considerable advances have been made to improve its physical and mechanical properties. Still how to predict its life-span is crucial since is related to the product warranty. Therefore, the present paper pave the way for further research using different fungi, matrices and reinforcement agents, since can estimate its mechanical and physical properties.

Knowledge of a WPC's resistance to microbial exposition is important for its adequate use indoors and outdoors, as well as its disposal and biodegradability. Although weight losses were not significant in four months, the fungus produced a biofilm under the WPC that create a special environment for lignocellulosic consuming. Even at a small rate, the fungus could produce microcracks in the WPC surface, which might also be assisted by water absorption. These changes can be the primary cause that influence losses of the mechanical properties, namely, impact strength and hardness. The thermal properties of the WPCs have also been modified as result of the lignocellulosic biodegradation, thus leading to a loss of viscosity and thermal stability.

The biodegradation of PP-based biocomposites depends on a number of factors, including the natural fiber content, its biodegradability, and the interphase/interface between the fibers and the 
matrix. Higher levels of natural fibers generally increase the degradation rate of PP-based composites. Coupling and reinforcement or fillers agents can affect biodegradation. The rate of biodegradation generally depends on the substrate composition and the existing microorganisms. The durability of PP-based biocomposites can be tailored through the use of additives.

Author Contributions: Conceptualization, I.C. and A.L.L.; Methodology, I.C. and D.R.N.; Formal Analysis, I.C.; Investigation, L.L.N.R., O.A.T.D. and D.R.N.; Resources, I.C. and A.L.L.; Writing-Original Draft Preparation, L.L.N.R., O.A.T.D. and D.R.N.; Writing-Review \& Editing, I.C. and A.L.L.; Supervision, I.C. and A.L.L.; Project Administration, I.C.; Funding Acquisition, I.C. and A.L.L.

Funding: The authors thank the CNPq, Fundação de Amparo à Pesquisa do Estado de São Paulo-FAPESP (2015/21395-9), and Coordenação de Aperfeiçoamento de Pessoal de Nivel Superior-CAPES for the financial support given for this research.

Acknowledgments: We thank José Raimundo de Souza Passos for the statistical analysis.

Conflicts of Interest: The authors declare no conflicts of interest.

\section{References}

1. Faruk, O.; Bledzki, A.K.; Fink, H.-P.; Sain, M. Progress report on natural fiber reinforced composites. Macromol. Mater. Eng. 2014, 299, 9-26. [CrossRef]

2. Wirasak, S.; Chollakup, R.; Nardin, M. Bio-Based Composites for High-Performance Materials: From Strategy to Industrial Application; CRC Press, Taylor and Francis Group: Boca Raton, FL, USA, 2014.

3. Sahari, J.; Sapuan, S.M.; El-Shekeil, Y.A.; Ishak, M.R.; Akhtar, R. Natural Fibre-Reinforced Thermoplastic Starch Composites in: Starch-Based Blends, Composites and Nanocomposites; The Royal Society of Chemistry: London, UK, 2016; pp. 109-142.

4. Visakh, P.M.; Mathew, A.P.; Thomas, S. Natural Polymers: Their Blends, Composites and Nanocomposites: State of Art, New Challenges and Opportunities; Springer: Berlin/Heidelberg, Germany, 2013.

5. Keskisaari, A.; Kärki, T. Raw material potential of recyclable materials for fiber composites: A review study. J. Mater. Cycles Waste Manag. 2016, 19, 1136-1143. [CrossRef]

6. Moore, J.R.; Cown, D.J. Processing of Wood for Wood Composites. In Wood Composites; Woodhead Publishing: Cambridge, UK, 2015; pp. 27-45.

7. Kuka, E.; Cirule, D.; Kajaks, J.; Janberga, A.; Andersone, I.; Andersons, B. Fungal degradation of wood plastic composites made with thermally modified wood residues. Key Eng. Mater. 2017, 721, 8-12. [CrossRef]

8. Morris, P.I.; Cooper, P. Recycled plastic/wood composite lumber attacked by fungi. For. Prod. J. 1998, 48, 86-88.

9. Schirp, A.; Ibach, R.E.; Pendleton, D.E.; Wolcott, M.P. Biological degradation of wood-plastic composites (WPC) and strategies for improving the resistance of WPC against biological decay. ACS Symp. Ser. 2008, 982, 480-507.

10. Leao, A.L.; Ferrao, P.C.; Souza, S.F. State-of-the-art for extrusion and injection moulding FPC: Natural fibre plastics composites in Brazil. Int. J. Mater. Prod. Technol. 2009, 36, 134-154. [CrossRef]

11. Faruk, O.; Bledzki, A.K.; Fink, H.P.; Sain, M. Biocomposites reinforced with natural fibers: 2000-2010. Prog. Polym. Sci. 2012, 37, 1552-1596. [CrossRef]

12. Gardner, D.J.; Han, Y.; Wang, L. Wood-Plastic Composite Technology. Curr. For. Rep. 2015, 1, 139-150. [CrossRef]

13. Azwa, Z.N.; Yousif, B.F.; Manalo, A.C.; Karunasena, W.A. Review on the degradability of polymeric composites based on natural fibres. Mater. Des. 2013, 47, 424-442. [CrossRef]

14. Najafi, S.K. Use of recycled plastics in wood plastic composites-A review. Waste Manag. 2013, 33, 1898-1905. [CrossRef] [PubMed]

15. Klein, R. Material properties of plastics. In Laser Welding of Plastics; Wiley-VCH Verlag GmbH \& Co. KgaA: Weinheim, Germany, 2012; pp. 3-69.

16. Lin, J.H.; Pan, Y.J.; Liu, C.F.; Huang, C.L.; Hsieh, C.T.; Chen, C.K.; Lin, Z.I.; Lou, C.W. Preparation and compatibility evaluation of polypropylene/high density polyethylene polyblends. Materials 2015, 8, 8850-8859. [CrossRef] [PubMed] 
17. Huda, M.S.; Mohanty, A.K.; Drzal, L.T.; Schut, E.; Mirsa, M. “Green” composites from recycled cellulose and poly(lactic acid): Physico-mechanical and morphological properties evaluation. J. Mater. Sci. 2005, 40, 4221-4229. [CrossRef]

18. Chavooshi, A.; Madhoushi, M.; Shakeri, A.; Khazaeian, A. A comparative study on the effects of material blending method on the physico-mechanical properties of WPCs made from MDF dust. J. Appl. Polym. Sci. 2014, 131, 40513. [CrossRef]

19. Pilla, S. Handbook of Bioplastics and Biocomposites Engineering Applications; John Wiley \& Sons: New York, NY, USA, 2011; p. 588.

20. Saba, N.; Tahir, P.; Jawaid, M. A review on potentiality of nano filler/natural fiber filled polymer hybrid composites. Polymers 2014, 6, 2247-2273. [CrossRef]

21. Yang, T.H.; Leu, S.Y.; Yang, T.H.; Lo, S.F. Optimized material composition to improve the physical and mechanical properties of extruded wood-plastic composites (WPCs). Constr. Build. Mater. 2012, 29, 120-127.

22. Dányádi, L.; Janecska, T.; Szabó, Z.; Nagy, G.; Móczó, J.; Pukánszky, B. Wood flour filled PP composites: Compatibilization and adhesion. Compos. Sci. Technol. 2007, 67, 2838-2846. [CrossRef]

23. Dittenber, D.B.; Gangarao, H.V.S. Critical review of recent publications on use of natural composites in infrastructure. Compos. Part A Appl. Sci. Manuf. 2012, 43, 1419-1429. [CrossRef]

24. Visakh, P.M.; Poletto, M. Polypropylene-Based Biocomposites and Bionanocomposites; Wiley: New York, NY, USA, 2018.

25. Shah, A.A.; Hasan, F.; Hameed, A.; Ahmed, S. Biological degradation of plastics: A comprehensive review. Biotechnol. Adv. 2008, 26, 246-265. [CrossRef] [PubMed]

26. Lucas, N.; Bienaime, C.; Belloy, C.; Queneudec, M.; Silvestre, F.; Nava-Saucedo, J.-E. Polymer biodegradation: Mechanisms and estimation techniques-A review. Chemosphere 2008, 73, 429-442. [CrossRef] [PubMed]

27. Lesage-Meessen, L.; Haon, M.; Uzan, E.; Levasseur, A.; Piumi, F.; Navarro, D.; Taussac, S.; Favel, A.; Lomascolo, A. Phylogeographic relationships in the polypore fungus Pycnoporus inferred from molecular data. FEMS Microbiol. Lett. 2011, 325, 37-48. [CrossRef] [PubMed]

28. Zimmermann, M.V.G.; Turella, T.C.; Santana, R.M.C.; Zattera, A.J. The influence of wood flour particle size and content on the rheological, physical, mechanical and morphological properties of EVA/wood cellular composites. Mater. Des. 2014, 57, 660-666. [CrossRef]

29. Schwarzkopf, M.J.; Burnard, M.D. Wood-plastic composites-Performance and environmental impacts. In Environmental Impacts of Traditional and Innovative Forest-Based Bioproducts; Springer: Singapore, 2016; pp. 19-43.

30. Brijwani, K.; Rigdon, A.; Vadlani, P.V. Fungal laccases: Production, function, and applications in food processing. Enzyme Res. 2010, 1-10. [CrossRef] [PubMed]

31. Kartal, S.N.; Aysal, S.; Terzi, E.; Yilgor, N.; Yoshimura, T.; Tsunoda, K. Wood and Bamboo-PP composites: Fungal and termite resistance, water absorption and FT-IR analyses. Bioresources 2013, 8, 1222-1244. [CrossRef]

32. Rodríguez-Delgado, M.; Orona-Navar, C.; García-Morales, R.; Hernandez-Luna, C.; Parra, R.; Mahlknecht, J.; Ornelas-Soto, N. Biotransformation kinetics of pharmaceutical and industrial micropollutants in ground waters by a laccase cocktail from Pycnoporus sanguineus CS43 fungi. Int. Biodeter. Biodegr. 2016, 108, $34-41$. [CrossRef]

33. Negrao, D.R.; Silva Júnior, T.A.F.; Passos, J.R.S.; Sansígolo, C.A.; Minhoni, M.T.A.; Furtado, E.L. Biodegradation of Eucalyptus urograndis by fungi. Int. Biodeter. Biodegr. 2014, 89, 95-102. [CrossRef]

34. Eira, A.F.; Minhoni, M.T.A. Manual Theoretical and Practical Cultivation of Edible Mushrooms, 2nd ed.; Foundation for Research and Agricultural and Forestry, FEPAF: São Paulo, Brazil, 1997.

35. ASTM D1238-04c. Standard Test Method for Melt Flow Rates of Thermoplastics by Extrusion Plastometer; ASTM International: West Conshohocken, PA, USA, 2004.

36. ASTM D256-10e1. Standard Test Methods for Determining the Izod Pendulum Impact Resistance of Plastics; ASTM International: West Conshohocken, PA, USA, 2010.

37. ASTM D2240-15. Standard Test Method for Rubber Property-Durometer Hardness; ASTM International: West Conshohocken, PA, USA, 2015.

38. ASTM D2017-05. Standard Test Method of Accelerated Laboratory Test of Natural Decay Resistance of Woods (Withdrawn 2014); ASTM International: West Conshohocken, PA, USA, 2005. 
39. Schinckel, A.P.; Craig, B.A. Evaluation of alternative nonlinear mixed effects models of swine growth. Prof. Anim. Sci. 2002, 18, 219-226. [CrossRef]

40. Nelder, J.A.; Wedderburn, W.M. Generalized linear models. J. R. Stat. Soc. Ser. A 1972, 135, 370-384. [CrossRef]

41. Liang, K.-Y.; Zeger, S.L. Longitudinal data analysis using generalized linear models. Biometrika 1986, 1, 13-22. [CrossRef]

42. Andrade, F.A.A.; Calonego, F.W.; Severo, E.T.; Furtado, E.L. Selection of fungi for accelerated decay in stumps of Eucalyptus spp. Bioresour. Technol. 2012, 11, 456-461. [CrossRef] [PubMed]

43. Negrao, D.R.; Sain, M.; Leao, A.L.; Sameni, J.; Jeng, R.; Jesus, J.P.F.; Monteiro, R.T.R. Fragmentation of lignin from organosol black liquor by White rot fungi. Bioresources 2015, 10, 1553-1573. [CrossRef]

44. Martínková, I.; Kotik, M.; Homolka, L. Biodegradation of phenolic compounds by Basidiomycota and its phenol oxidases: A review. Chemosphere 2016, 149, 373-382. [CrossRef] [PubMed]

45. Philip, M.; Attwood, J.; Hulme, A.; Williams, G.; Shipton, P. Evaluation of Weathering in Mixed Polyethylene and Polypropylene Products; The Waste \& Resources Action Programme: Oxon, UK, 2004; 113p.

46. Butnaru, E.; Darie-Niţă, R.N.; Zaharescu, T.; Balaeş, T.; Tănase, C.; Hitruc, G.; Doroftei, F.; Cornelia, V. Gamma irradiation assisted fungal degradation of the polypropylene/biomass composites. Rad. Phys. Chem. 2016, 125, 134-144. [CrossRef]

47. Fabiyi, J.S.; McDonald, A.G. Degradation of polypropylene in naturally and artificially weathered plastic matrix composites. Maderas Cienc. Tecnol. 2014, 16, 275-290. [CrossRef]

48. Wambua, P.; Ivens, J.; Verpoest, I. Natural fibers: Can they replace glass in fibre reinforced plastics? Compos. Sci. Technol. 2003, 63, 1259-1264. [CrossRef]

49. Skyba, O.; Douglas, C.J.; Mansfield, S.D. Syringyl-rich lignin renders poplars more resistant to degradation by wood decay fungi. Appl. Environ. Microbiol. 2013, 79, 2560-2571. [CrossRef] [PubMed]

50. Kord, B. Effect of wood flour content on the hardness and water uptake of thermoplastic polymer composites. World Appl. Sci. J. 2011, 12, 1632-1634.

51. Ghasemi, I.; Kord, B. Long-term water absorption behavior of polypropylene/wood flour/organoclay hybrid nanocomposite. Iran Polym. J. 2009, 18, 683-691.

52. Bledzki, A.K.; Gassan, J. Composites reinforced with cellulose based fibers. J. Polym. Sci. 1999, 24, $221-274$.

53. Hosseinihashemi, K.; Modirzare, M.; Safdari, V.; Kord, B. Decay resistance, hardness, water absorption and thickness swelling of a bagasse fiber/plastic composite. Bioresources 2011, 6, 3289-3299.

54. Fakhrul, T.; Islam, M.A. Degradation behavior of natural fiber reinforced polymer matrix composites. Procedia Eng. 2013, 56, 795-800. [CrossRef]

55. Verhey, S.; Laks, P.; Richter, D. Laboratory decay resistance of woodfiber/thermoplastic composites. For. Prod. J. 2001, 51, 44-49.

56. Mankowski, M.; Morrel, J.J. Patterns of fungal attack in wood plastic composites following exposure in a soil block test. Wood Fiber Sci. 2000, 32, 340-345.

57. Catto, A.L.; Montagna, L.S.; Almeida, S.H.; Silveira, R.M.B.; Santana, R.M.C. Wood plastic composites weathering: Effects of compatibilization on biodegradation in soil and fungal decay. Int. Biodeter. Biodegr. 2016, 109, 11-22. [CrossRef]

58. Simonsen, J.; Freitag, C.M.; Silva, A.; Morrell, J.J. Wood/plastic ratio: effect on performance of borate biocides against a brown rot fungus. Holzforschung 2004, 58, 205-208. [CrossRef]

59. Fabiyi, J.S.; McDonald, A.G. Physical morphology and quantitative characterization of chemical changes of weathered PVC/Pine composites. J. Polym. Environ. 2010, 18, 57-64. [CrossRef]

60. Lahtela, V.; Hamalainen, K.; Karki, T. The effect of preservatives on the properties of wood after modification. Balt. For. 2014, 20, 189-203.

61. Lopez, J.L.; Cooper, P.A.; Sain, M. Evaluate of proposed test methods to determine decay resistance of natural fiber plastic composites. For. Prod. J. 2005, 55, 95-99.

62. Zabihzadeh, S.M.; HosseiniHashemi, S.K.; MehreganNikoo, H.; Sepidehdam, S.M.J. Influence of fungal decay on physico-mechanical properties of a commercial extruded bagasse/PP composite. J. Reinf. Plast. Compos. 2009, 29, 1750-1756. [CrossRef]

63. H'ng, P.S.; Lee, A.N.; Hang, C.M.; Lee, S.H.; Khalina, A.; Paridah, M.T. Biological durability of injection moulded wood plastic composite boards. J. Appl. Sci. 2011, 11, 384-388. [CrossRef] 
64. Lomelí-Ramírez, M.G.; Ochoa-Ruiz, H.G.; Fuentes-Talavera, F.J.; García-Enriquez, S.; Cerpa-Gallegos, M.A.; Silva-Guzmán, J.A. Evaluation of accelerated decay of wood plastic composites by Xylophagus fungi. Int. Biodeter. Biodegr. 2009, 63, 1030-1035. [CrossRef]

65. Morrell, J.J.; Stark, N.M.; Pendleton, D.E.; McDonald, A.G. Durability of wood-plastic composites. Wood Des. Focus 2006, 16, 7-10.

66. Kaczmarek, H.; Oldak, D.; Malanowski, P.; Chaberska, H. Effect of short wavelength UV-irradiation on ageing of polypropylene/cellulose composition. Polym. Degrad. Stabil. 2005, 88, 189-198. [CrossRef]

67. Islam, M.S.; Hamdan, S.; Hasan, M.; Ahmed, A.S.; Rahman, M.R. Effect of coupling reactions on the mechanical and biological properties of tropical wood polymer composites (WPC). Int. Biodeter. Biodegr. 2012, 72, 108-113. [CrossRef]

68. Xu, F.; Yu, J.; Tesso, T.; Dowell, F.; Wang, D. Qualitative and quantitative analysis of lignocellulosic biomass using infrared techniques: A mini-review. Appl. Energy 2013, 104, 801-809. [CrossRef]

69. Butylina, S.; Hyvarinen, M.; Karki, T. Accelerated weathering of wood-polypropylene composites containing minerals. Compos. Part A Appl. Sci. Manuf. 2012, 43, 2087-2094. [CrossRef]

70. Li, Y.; Pickering, K.L.; Farrell, R.L. Determination of interfacial shear strength of white rot fungi treated hemp fibre reinforced polypropylene. Compos. Sci. Technol. 2009, 69, 1165-1171. [CrossRef]

71. Crabbe, J.R.; Campbell, J.R.; Thompson, L.; Walz, S.L.; Schultz, W.W. Biodegradation of a colloidal ester-based polyurethane by soil fungi. Int. Biodeterior. Biodegr. 1994, 33, 103-113. [CrossRef]

72. Luongo, J.P. Infrared study of polypropylene. J. Appl. Polym. Sci. 1960, 3, 302-309. [CrossRef]

73. Arteaga-Pérez, L.E.; Segura, C.; Bustamante-García, V.; Cápiro, O.G.; Jiménez, R. Torrefaction of wood and bark from Eucalyptus globulus and Eucalyptus nitens: Focus on volatile evolution vs feasible temperatures. Energy 2015, 93, 1731-1741. [CrossRef]

74. Fung, K.L.; Xing, X.S.; Li, R.K.Y.; Tjonga, S.C.; Mai, Y.W. An investigation on the processing of sisal fibre reinforced polypropylene composites. Compos. Sci. Technol. 2003, 63, 1255-1258. [CrossRef]

75. Ayrilmis, N.; Kaymakci, A.; Güleç, T. Potential use of decayed wood in production of wood plastic composite. Ind. Crops Prod. 2015, 74, 279-284. [CrossRef]

76. Zhang, C.; Xu, W.; Yan, P.; Liu, X.; Zhang, Z.C. Overcome the recalcitrance of eucalyptus bark to enzymatic hydrolysis by concerted ionic liquid pretreatment. Process Biochem. 2015, 50, 2208-2214. [CrossRef]

77. Yang, H.; Yan, R.; Chen, H.; Lee, D.H.; Zheng, C. Characteristics of hemicellulose, cellulose and lignin pyrolysis. Fuel 2007, 86, 1781-1788. [CrossRef]

78. Collard, F.X.; Blin, J. A review on pyrolysis of biomass constituents: Mechanisms and composition of the products obtained from the conversion of cellulose, hemicelluloses and lignin. Renew. Sustain. Energy Rev. 2014, 38, 594-608. [CrossRef]

79. Yu, J.; Paterson, N.; Blamey, J.; Millan, M. Cellulose, xylan and lignin interactions during pyrolysis oflignocellulosic biomass. Fuel 2017, 191, 140-149. [CrossRef]

80. Jakab, E.; Várhegyi, G.; Faix, O. Thermal decomposition of polypropylene in thepresence of wood-derived materials. J. Anal. Appl. Pyrolysis. 2000, 56, 273-285. [CrossRef]

(C) 2019 by the authors. Licensee MDPI, Basel, Switzerland. This article is an open access article distributed under the terms and conditions of the Creative Commons Attribution (CC BY) license (http://creativecommons.org/licenses/by/4.0/). 